\title{
I. Beditaquellen.
}

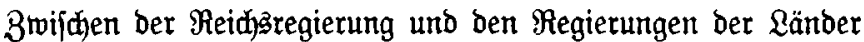

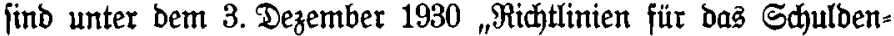
wejen ber Bemeinben" (nadjtehend als "neue Midttinien" bezeidnet) vereinbart tworden, bie eine Reuregelung bes tommunalen Rrebit= wejens barftellen. Die bereits im Jahre 1924 zmifden bem Meid

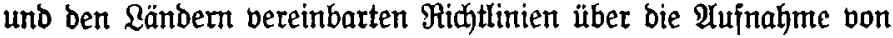

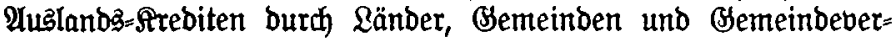

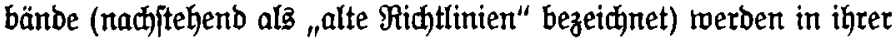

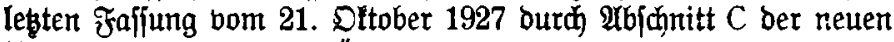

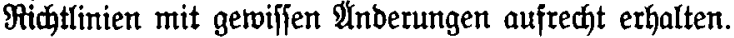

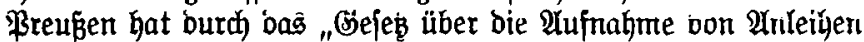
unb Darlehen jorvie die Utbernahme von Bürgidaften uno Bet= pplichtungen aus Berwährberträgen unb von anberen Sidherheiten Durch Bemeinben und Bemeinoeberbänbe" vom 29. Mai 1931 (SS.

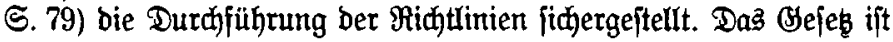
mit bem Tage feiner Betfünoung, am 3. Juni 1931 in $\mathfrak{R}$ raft getteten und bis zum 31. März 1933 befriftet. Dies entfpridyt ber für bie neuen

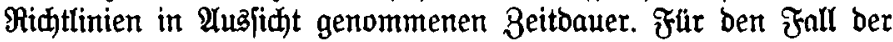

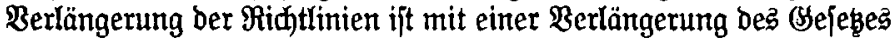

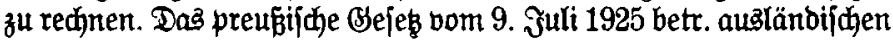

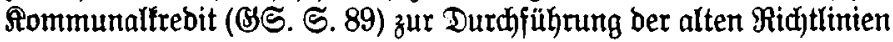
ift aufgehoben rorben.

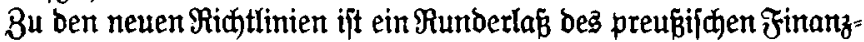
minifters und bes preupijichen Minifters bes Jnnern vom 5 . Februar

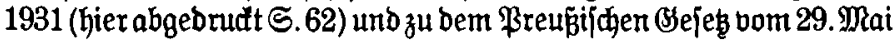

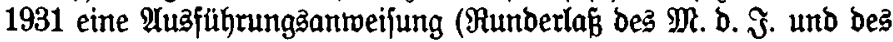
F. M. vom 17. Juuni 1931, hier abgebruđt Seite 73, nadjteheno QXus\}|ühnungsantweifung genannt) ergangen.

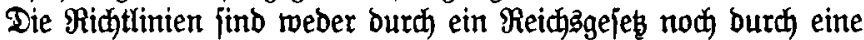
Reidazberorbnung mit Bsejebestraft erlafjen worben; fie haben baher

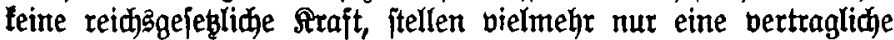

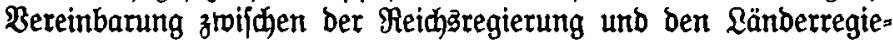
nungen bar. Die Bebingungen, bie in ben alten Midttlinien unt ben 
